\section{REFERENCES}

Bamber, J. L., Ekholm, S. and Krabill, W.B., 2001: A new, high-resolution digital elevation model of Greenland fully validated with airborne laser altimetry, Journal of Geophysical Research, 106(B4): 6733-6746, 10.1029/2000JB900365

Blunier, T. and Brook, E.J., 2001: Timing of millennialscale climate change in Antarctica and Greenland during the last glacial period, Science 291: 109-112.

Brook E. and Wolff, E., 2006: The future of ice core science, EOS, 87 (4): 39.

EPICA-community-members, 2004: Eight glacial cycles from an Antarctic ice core, Nature, 429: 623-628.
Lisiecki, L. E., and Raymo, M.E., 2005: A Pliocene-Pleistocene stack of 57 globally distributed benthic $\delta^{18} 0$ records, Paleoceanography, 20, doi:10.1029/.

NGRIP Members, 2004: High resolution record of northern hemisphere climate extending in to the last interglacial period, Nature, 431: 147-141.

Petit, J. R., Jouzel, J., Raynaud, D., Barkov, N.I., Barnola J.-M., Basile, I., Bender, M., Chappellaz, J., Davis, M., Delaygue, G., Masson-Delmotte, V., Kotlyakov, V.M., Legrand, M., Lipenkov, V.Y., Lorius, C., Pepin, L., Ritz, C., Saltzman, E., and Stievenard M., 1999: Climate and atmospheric history of the past 420,000 years from the Vostok ice core, Antarctica, Nature, 399: 429-436.
Schneider, D.P., 2005: Antarctic climate of the past 200 years from an integration of instrumental, satellite and ice core proxy data, Ph.D. Thesis, University of Washington, 2005

Siegenthaler, U., Stocker, T. F., Monnin, E., Lüthi, D. Schwander, J., Stauffer, B., Raynaud, D., Barnola J. -M., Fischer, H., Masson-Delmotte, V. and Jouzel, J. 2005: Stable carbon cycle-climate relationship during the late Pleistocene, Science, 310: 1313-1317.

\title{
The sea-floor drill rig "MeBo": Robotic retrieval of marine sediment cores
}

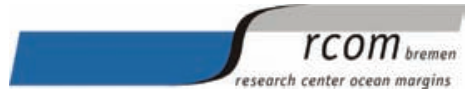

Tim Freudenthal and Gerold Wefer

Research Center Ocean Margins, University of Bremen, Germany; freuden@rcom-bremen.de, gwefer@rcom-bremen.de

Retrieval of marine sediment cores is conventionally carried out either by gravity coring or by drilling from a ship. Although a number of research vessels allow for gravity coring, the length of the retrieved cores is often shorter than desired. While this limitation can be overcome by drilling into deep-sea sediments, the availability and cost of drill-ships imposes a severe limitation on this approach. To bridge this gap in sediment-coring techniques, we developed a remotely operated underwater drill rig "MeBo" ("Meeresboden-Bohrgerät"; German for "sea-floor drill rig"). This portable drill can be operated from research vessels of opportunity. It is deployed on the sea floor and is capable of retrieving 50-m-long cores from sediments and hard rocks.

The drill is an electro-hydraulic system that is remotely controlled from the ship (Fig. 1). A steel armored umbilical with a diameter of $32 \mathrm{~mm}$ is used to lower the 10-tonheavy device to the sea bed, where four legs arm out in order to increase the stability of the rig. Copper wires and fiber optic cables within the umbilical supply energy from the vessel and allow communication between the MeBo and the control unit on deck. The system utilizes commercial rotary core barrels with diamond or tungsten carbide bits, as well as push coring barrels, and can set a casing as needed for various lithologies. The MeBo stores drilling rods and casing tubes, as well as push-coring and rotary barrels, on two rotating magazines that can be loaded with a

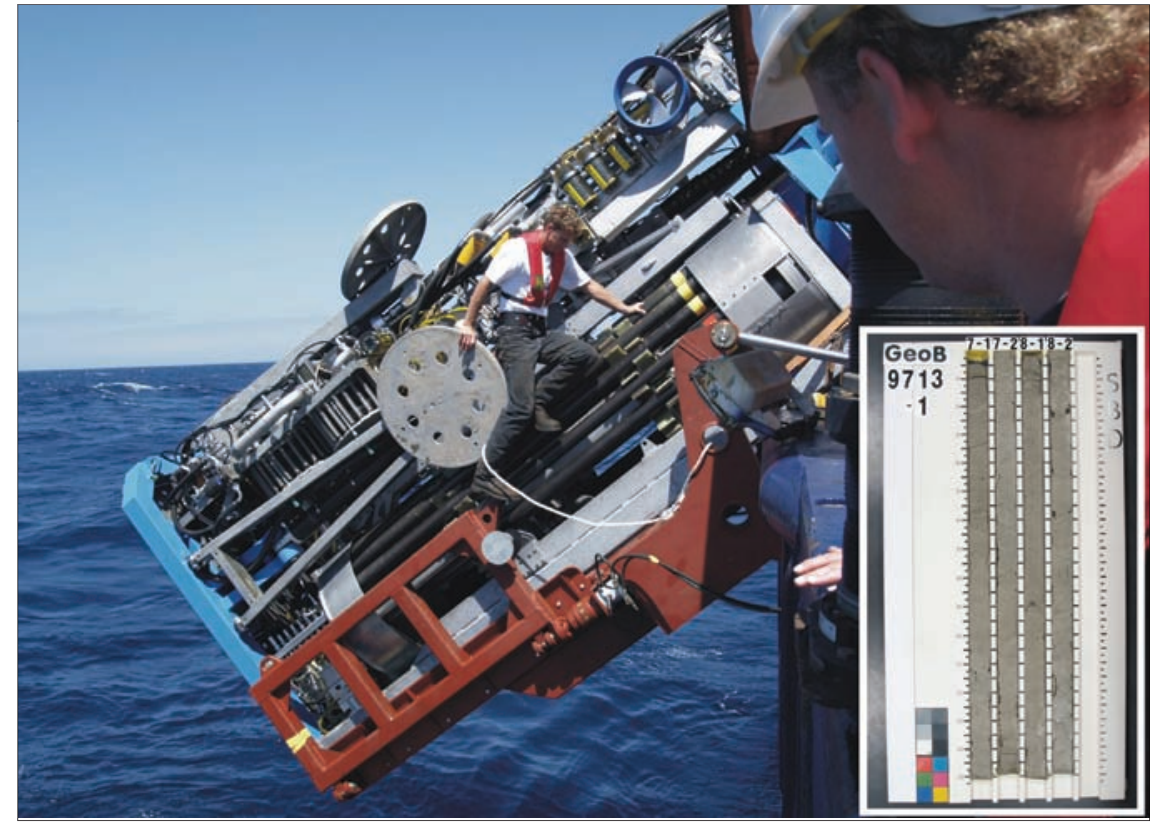

Fig. 1: Last checks on the newly developed sea-floor drill rig MeBo before the first deep-water test from the German research vessel METEOR. (Inset) Consolidated Pliocene marls retrieved by rotary drilling with the MeBo in $1700 \mathrm{~m}$ water depth off NW Africa.

mixture of tools specifically required for a drill job. The drill string is composed of 3-m sections. The MeBo has the capability to drill up to $50 \mathrm{~m}$ into the sea floor, to recover cores with 74-84 $\mathrm{mm}$ diameter, and to stabilize the drilled hole to a depth of $40 \mathrm{~m}$. The complete MeBo system, including drill, winch, launch and recovery system, control unit, as well as workshop and spare drill tools, is shipped within six 20' containers.

The MeBo was successfully tested on two cruises, from the research vessels METEOR (at the continental slope off NW Africa; cruise M65-3) and CELTIC EXPLORER (near the island of Rügen in the southern Baltic Sea; cruise CE0511). During theses tests, the MeBo was deployed ten times in 25-1700 m water depth, with a maximum drill depth of $23.65 \mathrm{~m}$. In total, about $105 \mathrm{~m}$ were drilled in sand, unconsolidated and consolidated marls, as well as glacial till. The total core length recovered was about $50 \mathrm{~m}$. Especially in cohesive sediments, a recovery rate of nearly $100 \%$ was achieved.

A major advantage of the MeBo compared to drill ships is that the drilling operations are independent of any ship movements due to waves, wind or currents. This allows the recovery of non-fractured cores of high quality (Fig. 1, inset). 